\title{
Genetic divergence among white-type acai palm accessions based on morpho-agronomic characters
}

\author{
Angela Maria de Sousa(1), Maria do Socorro Padilha de Oliveira ${ }^{(2)}$ and João Tomé de Farias Neto ${ }^{(2)}$
}

\begin{abstract}
(1)Universidade Federal Rural da Amazônia, Avenida Presidente Tancredo Neves, no 2.501, Terra Firme, CEP 66077-830 Belém, PA, Brazil. E-mail: agro angela@yahoo.com.br (2)Embrapa Amazônia Oriental, Travessa Dr. Enéas Pinheiro, s/no, Marco, Caixa Postal 48, CEP 66095-903 Belém, PA, Brazil. E-mail: socorro-padilha.oliveira@embrapa.br, joao.farias@embrapa.br
\end{abstract}

\begin{abstract}
The objective of this work was to quantify the genetic divergence among accessions of white-type acai palm (Euterpe oleracea), through morpho-agronomic characters. The accessions belong to the active acai palm germplasm bank of Embrapa Amazônia Oriental. Thirteen characters were evaluated in 26 accessions, originated from six municipalities in the state of Pará, Brazil. The data were subjected to deviance and multivariate analyses, based on the average Euclidean distance, and were grouped by Tocher's method and the unweighted pair group method with arithmetic mean (UPGMA). The accessions differed for eight characters. The distances among accessions ranged from 0.64 to 2.62, with an average of 1.36, and four groups were formed by Tocher's method and two by the UPGMA. Seven major components explained $88.03 \%$ of the variation, whose graphic dispersion showed the tendency of forming four groups. The characters weight of 100 fruits, number of rachillae per bunch, and fruit yield per bunch contributed the most to the divergence, and the accessions from the municipalities of Breves, Curralinho, and Limoeiro do Ajuru were the most divergent. Therefore, the accessions of white acai palm show strong divergence and variability, which favor the selection of desirable individuals.
\end{abstract}

Index terms: Euterpe oleracea, Euclidean distance, groupings.

\section{Divergência genética entre acessos de açaizeiro do tipo branco com base em caracteres morfoagronômicos}

Resumo - O objetivo deste trabalho foi quantificar a divergência genética entre acessos de açaizeiro (Euterpe oleracea) do tipo branco, por meio de caracteres morfoagronômicos. Os acessos pertencem ao Banco Ativo de Germoplasma do Açaí, da Embrapa Amazônia Oriental. Avaliaram-se 13 caracteres, em 26 acessos procedentes de seis municípios paraenses. Os dados foram submetidos às análises de deviance e multivariadas, com base na distância euclidiana média, com agrupamentos pelos métodos de Tocher e "unweighted pair group method with arithmetic mean" (UPGMA). Os acessos diferiram quanto a oito caracteres. As distâncias entre os acessos variaram de 0,64 a 2,62, com média de 1,36, tendo-se formado quatro grupos pelo método de Tocher e dois pelo UPGMA. Sete componentes principais explicaram $88,03 \%$ da variação, cuja dispersão gráfica mostrou a tendência de formação de quatro grupos. Os caracteres massa de cem frutos, número de ráquilas por cacho e rendimento de frutos por cacho foram os que mais contribuíram para a divergência, e os acessos dos municípios de Breves, Curralinho e Limoeiro do Ajuru foram os mais divergentes. Portanto, os acessos de açaizeiro branco expressam forte divergência e variabilidade, o que favorece a seleção de indivíduos desejáveis.

Termos para indexação: Euterpe oleracea, distância euclidiana, agrupamentos.

\section{Introduction}

Acai palm (Euterpe oleracea Mart.) is a perennial species that is widely distributed in the Amazon. Its natural habitat are the floodplains along the Amazon estuary in the state of Pará, Brazil, where it has several uses (Menezes et al., 2008; Favacho et al., 2011). Pará is the main producer and consumer of acai (Farias
Neto et al., 2012), which is usually served as a drink obtained from fresh and in natura pulp extracted from the fruit. The color of the epicarp of the fruit can be purple or yellowish-green (Oliveira et al., 2012). The purple type is known worldwide as energy boosting, with high nutritional value, containing antioxidants; the white-type or "tinga" acai is more restricted to the 
local and regional markets, which explains why there is little morphological, agronomical, and nutraceutical information on the species.

Studies on the estimated variability and genetic divergence between accessions stored in germplasm banks provide the necessary information to subsidize genetic improvement programs for any species (Oliveira et al., 2012; Gomes Junior et al., 2014). Using this information, the plant breeder is able to plan and define work strategies (Schuster et al., 2006; Cruz et al., 2011). Variability and genetic divergence can be inferred through several descriptors, which represent a group of inheritable characters, including morphological, agronomic, cytogenetic, biochemical, physiological, and molecular ones (Schuster et al., 2006; Afonso et al., 2014; Beovides García et al., 2014).

In most of collections, the morphological and agronomic characters stand out because of their low costs and ease in being detected and quantified (Andrade et al., 2011), especially the morphological ones, which are less affected by the environment and present a high heritability (Elameen et al., 2011; Vieira et al., 2013). These descriptors are fundamental to reveal the characteristics of new genetic materials, besides affecting decisively the choice of varieties by farmers and other interested parties.

Genetic divergence is estimated through predictive methods, using data from various morpho-agronomic characters - both qualitative and quantitative -, since they evaluate each plant multidimensionally, giving a holistic view of each genotype (Cruz et al., 2011). When these methods are used, the quantification of divergence is calculated through a measure of distance, such as, for example, the Euclidean distance, interpreted and visualized through multivariate procedures. In the case of the studied species and of other palm trees, some morpho-agronomic descriptors are tested in the germplasm, in order to quantify genetic divergence (Oliveira et al., 2006, 2007; Galate et al., 2012; Domiciano et al., 2015). The lack of documentation, description, and evaluation of the genetic materials in the existing collections is a limiting factor for studies on the conservation and use of plant germplasm; in the case of white acai, there is no information available in the literature.

The objective of this work was to quantify the genetic divergence among accessions of white-type acai palm, through morpho-agronomic characters.

\section{Materials and Methods}

Twenty-six accessions of white acai palm, stored in the active germplasm bank (BAG) of Embrapa Amazônia Oriental, located in the municipality of Belém, in the state of Pará, Brazil, were evaluated (Table 1). Each accession represents a free-pollination progeny, formed by fruit collected from six sources (municipalities in the state of Pará) in the floodplains of the Amazon estuary, at Marajó Island.

The BAG was established in February 2003, in an isolated area $\left(1^{\circ} 27^{\prime} 21^{\prime \prime} \mathrm{S}, 48^{\circ} 30^{\prime} 16^{\prime \prime} \mathrm{W}\right.$, at an altitude of $10.8 \mathrm{~m}$ ) - in order to prevent the flow of pollen from the purple type-, using live plants grown in field conditions, in a dryland area. The climate of the region, according to the Köppen-Geiger classification, corresponds to the hot and humid type (Afi), characterized by a rainy season with mean rainfall of $2,740 \mathrm{~mm}$, temperature of $26^{\circ} \mathrm{C}$, and relative humidity around $90 \%$. The experimental design was completely randomized, with ten replicates, and each plot was represented by one plant, spaced at $5 \times 5 \mathrm{~m}$, totaling 260 plants.

In each accession, 13 morpho-agronomic characters were analyzed, of which 5 were morphological and 8 agronomic. The morphological characters were evaluated once in 2015, whereas the agronomic ones, related to fruit production, were assessed from 2008 to 2014. Due to the loss of plants in this BAG, attributed to the poor adaptation to dry land conditions, lightning rays, among others, data were collected from a varying number of plants: for the morphological characters, from 5 to 10 plants, and for the agronomic ones, from 2 to 10 plants, totaling 219 and 163 plants, respectively (Table 1).

The morphological characters studied were: type of stipe (TS), according to a grade scale of 0 to 1 , in which 0 represents a solitary stipe, and 1 a clumpforming one; number of offshoots per plant (NSP); number of offshoots bearing fruit per plant (NSFP), by counting those on each plant; circumference of the offshoot at chest height (CSCH); and length of the internode (LIN), in centimeters, obtained from the oldest offshoot of the plant. In addition, the following agronomic characters were assessed: color of mature fruit (CorF), also in a grade scale, in which 1 stands for green and 2 for purple (segregants); total number of bunches (TNB), considered as the total sum of the bunches collected from each plant in the study period; total bunch weight (TBW) and fruit weight per bunch 
(FWB), in kilograms, represented by the mean weight of the bunches and of the fruits per bunch produced in the experimental period; fruit yield per bunch (FYB), in percentage, obtained by the ratio between the characters FWB and TWB; length of the rachis of the bunch (LRB), in centimeters; number of rachillae per bunch (NRB); and weight of 100 fruits (WHF), in grams, determined as the average of the weight of 100 fruits from each bunch, taking into consideration all the bunches collected during the evaluation period.

The analysis of deviance was carried out (Anadeve), using the Selegen software (Resende, 2007), since the experiment was unbalanced. In this kind of analysis, the effects are not tested by the F-test, but by the likelihood ratio test (LRT), by obtaining: the logarithm of the point of maximum residual likelihood (L), for models with or without effects to be tested; the deviance $(D)=-2 \log L$, for models with or without effects (heritability) to be tested; the difference between the deviances for models with or without effects (heritability) to be tested, in order to determine the likelihood ratio (LR); and the significance of this difference via the LRT, by means of the chi-square test with one degree of freedom.

The estimates of the genetic distances between the 26 accessions and the six sources evaluated were obtained from the average Euclidean distance between genotypes $\mathrm{i}$ and $\mathrm{i}^{\prime}\left(\mathrm{dg}_{\mathrm{ii}}\right)$, calculated using standard data, to eliminate the problem related to the grade scales, by the Genes software (Cruz, 2006). The standardization of data was done based on the formula: $\mathrm{x}_{\mathrm{ij}}=\mathrm{X}_{\mathrm{ij}} / \mathrm{S}\left(\mathrm{X}_{\mathrm{j}}\right)$, in which $\mathrm{x}_{\mathrm{ij}}$ is the standardized data; $\mathrm{X}_{\mathrm{ij}}$ is the observation made in the $\mathrm{i}$-th genotype $(i=1,2, \ldots, 26$ for the accessions, and $i=1,2, \ldots, 6$ for the sources, in relation to the $\mathrm{j}$-th character selected $\mathrm{j}=1,2, \ldots, 13)$; and $\mathrm{S}\left(\mathrm{X}_{\mathrm{j}}\right)$ is the standard deviation of the

Table 1. Identification of the 26 evaluated accessions of white-type acai palm (Euterpe oleracea), stored in the active acai palm germplasm bank of Embrapa Amazônia Oriental, located in the municipality of Belém, in the state of Pará, Brazil.

\begin{tabular}{|c|c|c|c|c|c|}
\hline Accession & $\begin{array}{c}\text { Source } \\
\text { (municipalities of Pará) }\end{array}$ & Latitude & Longitude & $\begin{array}{l}\text { Altitude } \\
(\mathrm{m})\end{array}$ & No. of plants evaluated ${ }^{(1)}$ \\
\hline 1 & Breves & $1^{\circ} 40^{\prime} 57^{\prime \prime}$ & $50^{\circ} 28^{\prime} 51^{\prime \prime}$ & 10 & $3,4,5,7,8,9,10$ \\
\hline 2 & Breves & $1^{\circ} 40^{\prime} 57^{\prime \prime}$ & $50^{\circ} 28^{\prime} 51^{\prime \prime}$ & 10 & $1,2,3,4,6,7,8,9,10$ \\
\hline 3 & Breves & $1^{\circ} 40^{\prime} 57^{\prime \prime}$ & $50^{\circ} 28^{\prime} 51^{\prime \prime}$ & 10 & $1,3,5,6,7,8,(9), 10$ \\
\hline 4 & Breves & $1^{\circ} 40^{\prime} 57^{\prime \prime}$ & $50^{\circ} 28^{\prime} 51^{\prime \prime}$ & 10 & $1,4,5,6,7,10$ \\
\hline 5 & Curralinho & $0^{\circ} 32^{\prime} 11^{\prime \prime}$ & $49^{\circ} 11^{\prime} 4^{\prime \prime}$ & 40 & $1,2,3,4,5,6,7,8,9,10$ \\
\hline 6 & Curralinho & $0^{\circ} 32^{\prime} 11^{\prime \prime}$ & $49^{\circ} 11^{\prime} 4^{\prime \prime}$ & 40 & $1,2,3,4,5,6,7,9,10$ \\
\hline 7 & Curralinho & $0^{\circ} 32^{\prime} 11^{\prime \prime}$ & $49^{\circ} 11^{\prime} 4^{\prime \prime}$ & 40 & $1,2,3,4,5,6,7,8,9,10$ \\
\hline 8 & Curralinho & $0^{\circ} 32^{\prime} 11^{\prime \prime}$ & $49^{\circ} 11^{\prime} 4^{\prime \prime}$ & 40 & $1,2,3,5,7,8,9,10$ \\
\hline 9 & Limoeiro do Ajuru & $1^{\circ} 53^{\prime} 53^{\prime \prime}$ & $49^{\circ} 23^{\prime} 27^{\prime \prime}$ & 4 & $1,2,3,4,5,6,7,8,9,10$ \\
\hline 10 & Limoeiro do Ajuru & $1^{\circ} 53^{\prime} 53^{\prime \prime}$ & $49^{\circ} 23^{\prime} 27^{\prime \prime}$ & 4 & $1,2,3,4,5,6,7,8,9,10$ \\
\hline 11 & Limoeiro do Ajuru & $1^{\circ} 53^{\prime} 53^{\prime \prime}$ & $49^{\circ} 23^{\prime} 27^{\prime \prime}$ & 4 & $1,2,3,5,7,9$ \\
\hline 12 & Muaná & $1^{\circ} 31^{\prime} 2^{\prime \prime}$ & $49^{\circ} 13^{\prime} 3^{\prime \prime}$ & 11 & $1,2,3,4,6,9,10,11,12,13,15$ \\
\hline 13 & Muaná & $1^{\circ} 31^{\prime \prime \prime}$ & $49^{\circ} 13^{\prime} 3^{\prime \prime}$ & 11 & $1,2,3,4,6,7,8,9,10$ \\
\hline 14 & Muaná & $1^{\circ} 31^{\prime \prime \prime}$ & $49^{\circ} 13^{\prime} 3^{\prime \prime}$ & 11 & $1,3,4,5,6,7,8,9,10$ \\
\hline 15 & Ponta de Pedras & $1^{\circ} 23^{\prime} 26^{\prime \prime}$ & $48^{\circ} 52^{\prime} 13^{\prime \prime}$ & 8 & $1,2,3,5,6,7,9,10$ \\
\hline 16 & Ponta de Pedras & $1^{\circ} 23^{\prime} 26^{\prime \prime}$ & $48^{\circ} 52^{\prime} 13^{\prime \prime}$ & 8 & $1,2,3,4,5,7,8,9,10$ \\
\hline 17 & Ponta de Pedras & $1^{\circ} 23^{\prime} 26^{\prime \prime}$ & $48^{\circ} 52^{\prime} 13^{\prime \prime}$ & 8 & $1,2,4,5,6,7,8$ \\
\hline 18 & Ponta de Pedras & $1^{\circ} 23^{\prime} 26^{\prime \prime}$ & $48^{\circ} 52^{\prime} 13^{\prime \prime}$ & 8 & $1,2,3,4,5,6,7,8,9,10$ \\
\hline 19 & Ponta de Pedras & $1^{\circ} 23^{\prime} 26^{\prime \prime}$ & $48^{\circ} 52^{\prime} 13^{\prime \prime}$ & 8 & $2,3,4,5,7,8,9,10$ \\
\hline 20 & Ponta de Pedras & $1^{\circ} 23^{\prime} 26^{\prime \prime}$ & $48^{\circ} 52^{\prime} 13^{\prime \prime}$ & 8 & $2,6,7,9$ \\
\hline 21 & Muaná & $1^{\circ} 31^{\prime} 42^{\prime \prime}$ & $49^{\circ} 13^{\prime} 3^{\prime \prime}$ & 11 & $1,2,3,4,5,6,7,8,9,10$ \\
\hline 22 & Muaná & $1^{\circ} 31^{\prime} 42^{\prime \prime}$ & $49^{\circ} 13^{\prime} 3^{\prime \prime}$ & 11 & $1,2,3,4,5,7,8,9,10$ \\
\hline 23 & São Sebastião da Boa Vista & $1^{\circ} 42^{\prime} 47^{\prime \prime}$ & $49^{\circ} 33^{\prime} 10^{\prime \prime}$ & 6 & $1,3,4,5,7,8,9,10$ \\
\hline 24 & São Sebastião da Boa Vista & $1^{\circ} 42^{\prime} 47^{\prime \prime}$ & $49^{\circ} 33^{\prime} 10^{\prime \prime}$ & 6 & $1,3,5,6,8,10$ \\
\hline 25 & São Sebastião da Boa Vista & $1^{\circ} 42^{\prime} 47^{\prime \prime}$ & $49^{\circ} 33^{\prime} 10^{\prime \prime}$ & 6 & $1,2,4,5,6,7,8,9$ \\
\hline 26 & São Sebastião da Boa Vista & $1^{\circ} 42^{\prime} 47^{\prime \prime}$ & $49^{\circ} 33^{\prime} 10^{\prime \prime}$ & 6 & $1,2,3,4,5,6,7,8,9,10$ \\
\hline Total & & & & & 219 \\
\hline
\end{tabular}

(1)Identification of the plants that provided the agronomic data for the multivariate analysis and the analysis of deviance. 
$\mathrm{j}$-th character. The average Euclidean distance between genotypes $\mathrm{i}$ and $\mathrm{i}^{\prime}\left(\mathrm{dg}_{\mathrm{iii}}\right)$ was calculated according to Cruz et al. (2011), through the following formula:

$$
\operatorname{dgii}^{\prime}=\sqrt{\frac{1}{\mathrm{n}} \sum_{\mathrm{j}}\left(\mathrm{x}_{\mathrm{ij}}-\mathrm{x}_{\mathrm{ij}}\right)^{2}},
$$

in which $\mathrm{n}$ is the number of characters analyzed.

The genetic distances obtained between the pairs of accessions and sources were interpreted and visualized using two methods: the unweighted pair group method with arithmetic mean (UPGMA), in which the consistency of the groups was evaluated based on the bootstrap analysis with 1,000 replicates; and Tocher's method, considered to be non-hierarchical, generated by the Genes software (Cruz, 2006). The UPGMA consists of establishing a dendrogram, whose construction is determined by the most similar genotype, in which the distance $\left(\mathrm{d}_{(\mathrm{ij}) \mathrm{k}}\right)$ between a $\mathrm{k}$ individual and a group (accessions or sources) formed by the $\mathrm{i}$ and $\mathrm{j}$ individuals is given by: $\mathrm{d}_{(\mathrm{ij}) \mathrm{k}}=$ average $\left(\mathrm{d}_{\mathrm{ik}} ; \mathrm{d}_{\mathrm{jk}}\right)$. Tocher's method establishes that the distance between the $\mathrm{k}$ individual and the group (accessions or sources) formed by the $\mathrm{i}$ and $\mathrm{j}$ individuals is given by: $\mathrm{d}_{(\mathrm{ij}) \mathrm{k}}=\mathrm{d}_{\mathrm{ij}}+\mathrm{d}_{\mathrm{jk}}$, in which the inclusion or not of the $\mathrm{k}$ individual occurs, respectively, if: $\mathrm{d}_{\text {(group) }} / \mathrm{n} \leq \theta$ and $\mathrm{d}_{\text {(group)k }} / \mathrm{n}>\theta$ in which $\mathrm{n}$ is the number of individuals that make up the original group, and $\theta$ is the value provided by the software.

The principal components analysis (PCoA) and the analysis of the relative importance of the characters for genetic divergence were performed for the accessions and their sources, using the Singh method (Singh, 1981); both analyses were carried out with the Genes software (Cruz, 2006).

\section{Results and Discussion}

Of all the evaluated characters, only NSP, TBW, FWB, FYB, and WHF showed significant differences between the accessions, at $5 \%$ probability, and $\mathrm{CSCH}$, LRB, and NRB differed at $1 \%$ probability (Table 2 ). It should be highlighted that these eight characters are already considered important for the selection of progenies of purple-type acai, since they can be used to obtain considerable gains in fruit yield in acai palm breeding programs (Farias Neto et al., 2007, 2012).

The Euclidean distances between the accessions varied between 0.64 and 2.62, with an average of 1.36 , which shows a great divergence between them. Oliveira et al. (2007) also reported a strong genetic divergence, while evaluating 87 accessions of the purple type of acai, through 22 morpho-agronomic descriptors, including the majority of the characters evaluated in the present study. A great divergence between the matrixes of acai palms, which occur naturally in different areas, was also observed by Galate et al. (2014). The greatest dissimilarity $\left(\mathrm{d}_{\mathrm{ij}}=2.62\right)$ was found between accessions 1 and 11 from the municipalities of Breves and Limoeiro do Ajuru, respectively, while the lowest $\left(\mathrm{d}_{\mathrm{ij}}=0.64\right)$ was registered between accessions 18 and 19, both from Ponta de Pedras. Approximately half $(45 \%)$ of the pairs of accessions of white acai presented dissimilarity above average, which shows the accentuated genetic divergence in the studied material.

Accession 1, from Breves, was the most divergent, when compared with nine accessions $(17,12,13,5,16$, $7,25,10$, and 6) from the other locations, with distances of $\mathrm{d}_{\mathrm{ij}}=2.53$ to 2.15. Accession 11, from Limoeiro do Ajuru, also showed high divergence, especially in relation to accessions 3 and 4 , with $\mathrm{d}_{\mathrm{ij}}=2.06$ and 2.15, respectively, both from the municipality of Breves. It has been reported that samples of acai palm from Breves differ greatly from those from Oiapoque, in the state of Amapá, Brazil (Oliveira et al., 2007), which showed great phenotypic variations between each other. Therefore, this region could be indicated as a promising area for the collection of germplasm and, also, for the conservation of the species, by adopting on farm or ex situ strategies.

For the group of accessions evaluated, crossings between the most divergent accessions are recommended, in order to obtain individuals with more vigor and a more heterotic effect, mainly among those presenting a superior performance in terms of the character fruit or palm heart production. However, the more similar individuals could be eliminated, in order to reduce costs and labor in the active germplasm bank (Schuster et al., 2006; Cruz et al., 2011).

When the genetic distances obtained per source were analyzed, a variation of 0.85 to 1.89 , with an average of 1.30, was observed. The longest distance was found between Breves and Ponta de Pedras, and the shortest one between Curralinho and Muaná. These results confirm the high divergence in the acai palm germplasm from the municipality of Breves. 
The visualization of the distances, obtained between the pairs of accessions using the UPGMA, allowed for the formation of two divergent groups, with $100 \%$ bifurcation consistency (Figure $1 \mathrm{~A}$ ): group I, consisting of two accessions (1 and 4), both originating from Breves; and group II, of 24 accessions, that is, with more than $92 \%$ of the evaluated material, organized in several subgroups. Similar results were found by Yokomizo et al. (2012) and Galate et al. (2014), when studying the germplasm of purple acai palm from different locations, also through morphoagronomic characters, using the same method.

Regarding the formation of subgroups, only two were formed in group II, at the genetic distance of $93.25 \%$, whose bifurcation consistency was $65.2 \%$ (Figure 1 A). Group IIa was represented by accession 3, originating from Breves, and IIb by the other accessions, for which four small conglomerates at $77 \%$ dissimilarity were observed; the one made up of accessions 2, 11, 13, and 17 had a high consistency of $88.9 \%$.

In general, the dendrogram showed that $64 \%$ of the groups formed were reliable and that all distances regarding the accessions from Breves were significant. Other accessions, including two from Curralinho (5 and 6) and from Limoeiro do Ajuru (11 and 9), also stood out due to their distances in the formation of the groups and subgroups. Since, there was at least one accession from Breves in the divergent groups formed by this method, it is possible that the accessions from this source present a discriminant character or specificities that the others do not.

In the dendrogram generated according to sources, two divergent groups were formed: group I, consisting only of Breves; and group II, encompassing the other sources (Figure 1 B). The bootstrap test showed significance in the formation of these two groups with $100 \%$ bifurcation consistency, which confirms the high divergence between the accessions from Breves, in comparison with those from the other locations.

Regarding accessions, four divergent groups were formed by Tocher's method (Table 3). Groups II and III were similar to those obtained by the UPGMA, which shows, once again, the divergence of the accessions from Breves, especially accessions 1, 4, and 3; the latter formed a group isolated from the other ones. Accession 11, from Limoeiro do Ajuru, was also isolated, as observed with the UPGMA. Regarding sources, two groups were formed by Tocher's method, with the same make up as in the UPGMA. Oliveira et al. (2007) and Galate et al. (2014) used the same methods and obtained similar results, when determining the genetic divergence among purple acai palms. This divergence could be due to a strong effect of the origin of the acai crops, most of them from the floodplains around the Amazon estuary, which are inundated areas affected by the movement of the tides, i.e., inundation occurs daily, according to the ebb and flow of the waters from the rivers and creeks, with an indirect link to the movement of the sea (Marinho, 2009).

Table 2. Analyses of deviance of the characters number of stipes per plant (NSP), number of fruiting offshoots per plant (NFSP), circumference at chest height (CSCH), length of five internodes (LIN), total number of bunches (TNB), total bunch weight (TBW), fruit weight per bunch (FWB), fruit yield per bunch (FYB), length of the rachis of the bunch (LRB), number of rachillae per bunch (NRB), and weight of 100 fruits (WHF), evaluated in 26 accessions of white acai palm (Euterpe oleracea), stored in the active acai palm germplasm bank of Embrapa Amazônia Oriental, located in the municipality of Belém, in the state of Pará, Brazilil ${ }^{(1)}$.

\begin{tabular}{|c|c|c|c|c|c|c|c|c|c|c|c|c|}
\hline \multirow[t]{2}{*}{ Effect } & \multicolumn{2}{|c|}{ NSP } & \multicolumn{2}{|c|}{ NFSP } & \multicolumn{2}{|c|}{$\mathrm{CSCH}$} & \multicolumn{2}{|c|}{ LIN } & \multicolumn{2}{|c|}{ TNB } & \multicolumn{2}{|c|}{ TBW } \\
\hline & Deviance & LRT & Deviance & LRT & Deviance & LRT & Deviance & LRT & Deviance & LRT & Deviance & LRT \\
\hline Accession & 950.15 & $4.16^{*}$ & 470.87 & $2.12^{\text {ns }}$ & 913.14 & $12.40 * *$ & $1,173.96$ & $0.01^{\mathrm{ns}}$ & 632.30 & $2.79^{\text {ns }}$ & 428.24 & $6.35^{*}$ \\
\hline Complete model & 945.54 & - & 468.75 & - & 900.74 & - & $1,173.95$ & - & 629.51 & - & 421.89 & - \\
\hline \multirow[t]{2}{*}{ Effect } & \multicolumn{2}{|c|}{ FWB } & \multicolumn{2}{|c|}{ FYB } & \multicolumn{2}{|c|}{ LRB } & \multicolumn{2}{|c|}{ NRB } & \multicolumn{2}{|c|}{ WHF } & - & - \\
\hline & Deviance & LRT & Deviance & LRT & Deviance & LRT & Deviance & LRT & Deviance & LRT & - & - \\
\hline Accession & 351.16 & $4.03 *$ & $1,665.93$ & $6.30 *$ & $1,465.36$ & $7.16^{* *}$ & $1,711.34$ & $9.36 * *$ & $2,031.36$ & $4.27 *$ & - & - \\
\hline Complete model & 347.13 & - & $1,659.63$ & - & $1,458.20$ & - & $1,701.98$ & - & $2,027.09$ & - & - & - \\
\hline
\end{tabular}

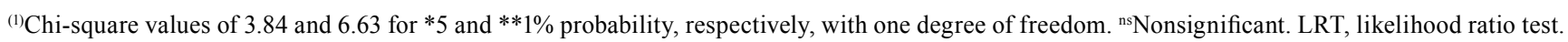


In the Amazon estuary, the water, as it invades the floodplains, deposits larger and heavier debris near the river banks, while tiny particles and lighter substances, such as seeds, are transported to more distant points. These environmental conditions, in which most acai crops are found, are peculiar and could favor the migration of the seeds from one municipality to another or from one population to another. Furthermore, the intense commercialization, in the 1940s, of fruits of this palm among municipalities, especially between Muaná and São Sebastião da Boa Vista, caused the seeds to undergo a strong anthropogenic flow (exchanges between riverside dwellers), which must also have contributed to the migration process of the acai palm populations (Marinho, 2009).
Migration corresponds to the incorporation of individuals and alleles in a particular population, and is much greater in nearby populations than in those that are geographically distant (Ramalho et al., 2012). A greater divergence was found for the accessions of the municipalities of Breves and Curralinho, which are further away geographically from São Sebastião da Boa Vista, Muaná, Ponta de Pedras, and Limoeiro do Ajuru.

The PCoA showed that the first seven components explained $88.03 \%$ of the total genetic variation found in the accessions of white acai palm, and that the remainder was distributed gradually throughout the other components (Table 4). The first component was responsible for $27.82 \%$ of the total variation, and the

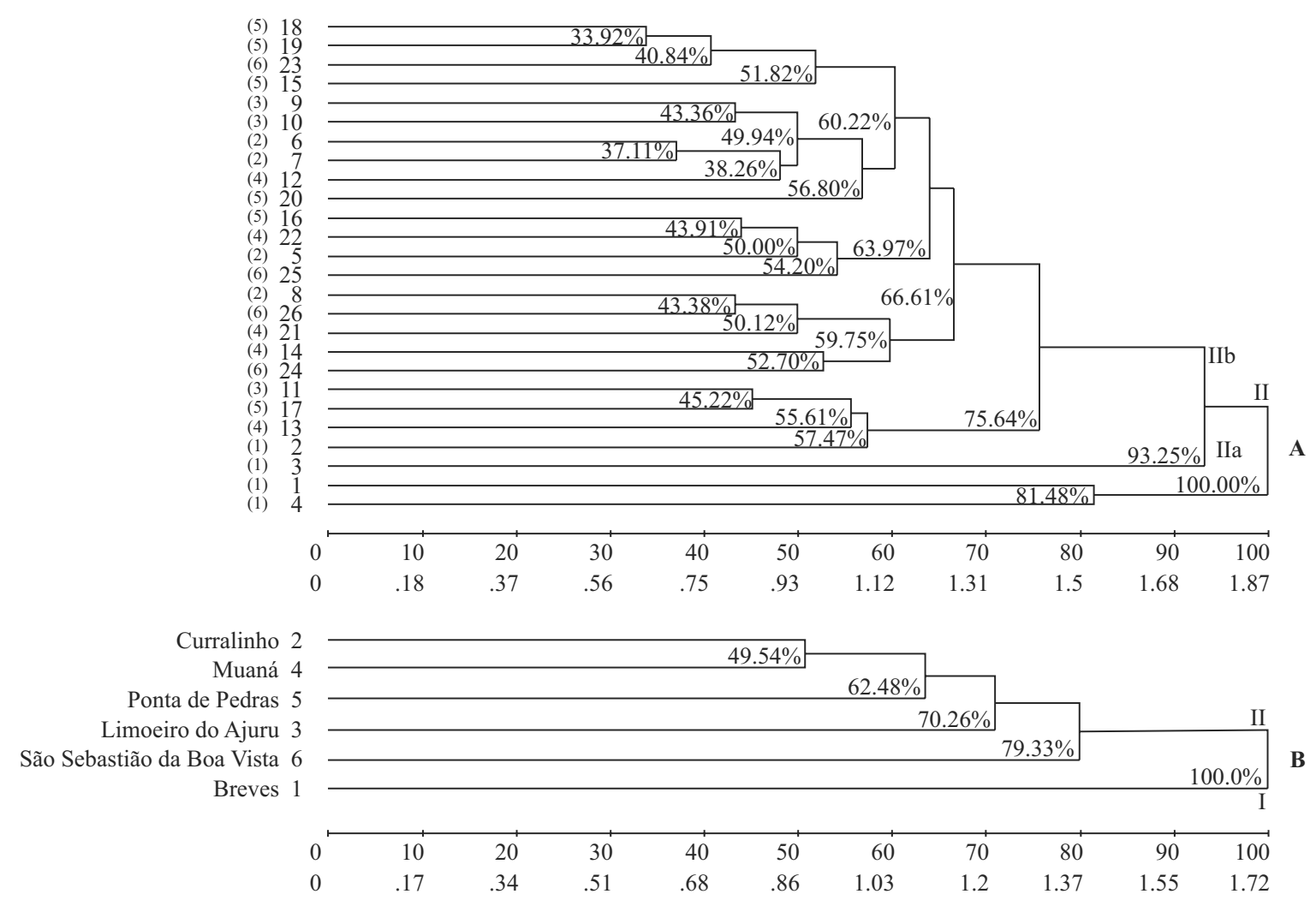

Figure 1. Groups formed by the unweighted pair group method with arithmetic mean (UPGMA) among 26 accessions (A) and six sources (municipalities) (B) of white-type acai palm (Euterpe oleracea), stored in the active acai palm germplasm bank of Embrapa Amazônia Oriental, located in the municipality of Belém, in the state of Pará, Brazil, using Euclidean distances obtained from the following 13 morpho-agronomic characters: type of stipe, number of offshoots, number of fruiting offshoots, circumference of the offshoot at chest height, length of five internodes, color of the mature fruit, total number of bunches, total bunch weight, fruit weight per bunch, fruit yield per bunch, length of the rachis of the bunch, number of rachillae per bunch, and weight of 100 fruits. 
second and third ones, respectively, for 43 and $56 \%$. Similar values were found by Oliveira et al. (2007) and Galate et al. (2012), who evaluated samples of purple acai palm from different locations in the Amazon Estuary, using the same morpho-agronomic descriptors. However, in the present study, the percentage of variation accumulated up to the eighth component was much greater - above $92 \%$.

The graphic dispersion based on the three first principal components showed a tendency of forming four groups of accessions: groups I and II, considered the most divergent, were formed by the most disperse accessions, 1 and 3, from the municipality of Breves; group III, included accessions 2, 11, 12, 13, and
17, which were more affected by the first principal component, in which accession 11, from Limoeiro do Ajuru, was the only one near the axis of the third principal component; and group IV, was formed by the other accessions (Figure 2 A). As to sources, the first three components were responsible for the formation of five groups of dispersion, in which Breves was the most distant (Figure 2 B). These results are in alignment with those obtained using the UPGMA and Tocher's method, and express the high divergence between the accessions from Breves and the other locations.

Regarding the relative contribution of the characters evaluated for divergence, it was verified that WHF

Table 3. Groups formed by Tocher's method among 26 accessions and six sources (municipalities) of white acai palm (Euterpe oleracea), stored in the active acai palm germplasm bank of Embrapa Amazônia Oriental, located in the municipality of Belém, in the state of Pará, Brazil, using Euclidean distances, based on the 13 following morpho-agronomic characters: type of stipe, number of offshoots, number of fruiting offshoots, circumference of the offshoot at chest height, length of the internode, color of the mature fruit, total number of bunches, total bunch weight, fruit weight per bunch, fruit yield per bunch, length of the rachis of the bunch, number of rachillae per bunch, and weight of 100 fruits.

\begin{tabular}{lc}
\hline Group & Accession \\
\hline I & $18,19,23,8,10,9,6,12,22,20,7,15,14,5,16,26,13,21,25,2,17,24$ \\
II & 1,4 \\
III & 3 \\
IV & 11 \\
\hline Group & Curralinho, Limoeiro do Ajuru, Muaná, Ponta de Pedras, and São Sebastião da Boa Vista \\
\hline I & Breves \\
II & \\
\hline
\end{tabular}

Table 4. Estimates of the eigenvalues of the main components and their respective percentages of variance and accumulated variance for 13 morpho-agronomic characters, as well as the relative contribution of these characters for divergence in 26 accessions and six sources (municipalities) of white-type acai palm (Euterpe oleracea), stored in the active acai palm germplasm bank of Embrapa Amazônia Oriental, located in the municipality of Belém, in the state of Pará, Brazil.

\begin{tabular}{|c|c|c|c|c|c|}
\hline Main component & Eigenvalue & $\begin{array}{c}\text { Variance } \\
(\%)\end{array}$ & $\begin{array}{l}\text { Accumulated } \\
\text { variance (\%) }\end{array}$ & $\begin{array}{c}\text { Contribution } \\
\text { per accession (\%) }\end{array}$ & $\begin{array}{c}\text { Contribution } \\
\text { per source }(\%)\end{array}$ \\
\hline 1 Type of stipe & 3.617 & 27.82 & 27.82 & 0.0 & 0.0 \\
\hline 2 Number of offshoots per plant & 2.085 & 16.03 & 43.86 & 1.8 & 2.6 \\
\hline 3 Number of fruiting offshoots per plant & 1.577 & 12.13 & 56.00 & 0.1 & 0.3 \\
\hline 4 Circumference of the offshoot at chest height $(\mathrm{cm})$ & 1.211 & 9.32 & 65.32 & 2.0 & 3.5 \\
\hline 5 Length of five internodes $(\mathrm{cm})$ & 1.139 & 8.76 & 74.09 & 2.9 & 4.2 \\
\hline 6 Color of the mature fruit & 1.087 & 8.36 & 82.46 & 0.0 & 0.0 \\
\hline 7 Total number of bunches & 0.724 & 5.57 & 88.03 & 0.6 & 0.0 \\
\hline 8 Total bunch weight $(\mathrm{kg})$ & 0.538 & 4.14 & 92.17 & 0.1 & 0.1 \\
\hline 9 Fruit weight per bunch $(\mathrm{kg})$ & 0.438 & 3.37 & 95.55 & 0.1 & 0.0 \\
\hline 10 Fruit yield per bunch (\%) & 0.257 & 1.98 & 97.53 & 7.9 & 15.4 \\
\hline 11 Length of the rachis of the bunch $(\mathrm{cm})$ & 0.217 & 1.67 & 99.20 & 1.3 & 5.1 \\
\hline 12 Number of rachillae per bunch & 0.096 & 0.74 & 99.94 & 6.4 & 12.3 \\
\hline 13 Weight of 100 fruits $(\mathrm{g})$ & 0.006 & 0.05 & 100.0 & 76.7 & 55.8 \\
\hline
\end{tabular}


had the greatest effect $(76.7 \%)$ on the formation of the groups (Table 4). Other characters that had a relative participation in the observed divergence were: FYB, with $7.9 \%$ for accessions and $15.4 \%$ for sources; and NRB, with $6.4 \%$ for accessions and $12.3 \%$ for sources. Both of these characters had already been reported as important for the selection of progenies of purple acai palms, aiming at fruit production (Farias Neto et al., 2008; Teixeira et al., 2012; Oliveira et al., 2015; Yokomizo et al., 2016). Moreover, the first character stood out because it facilitates the choice, by the breeder, of progenies according to fruit size - small fruits are preferred by sellers, due to the larger amount of pulp after being processed (Farias Neto et al., 2011). Nunes et al. (2010) pointed out that, besides being important for the selection of the best genotypes in
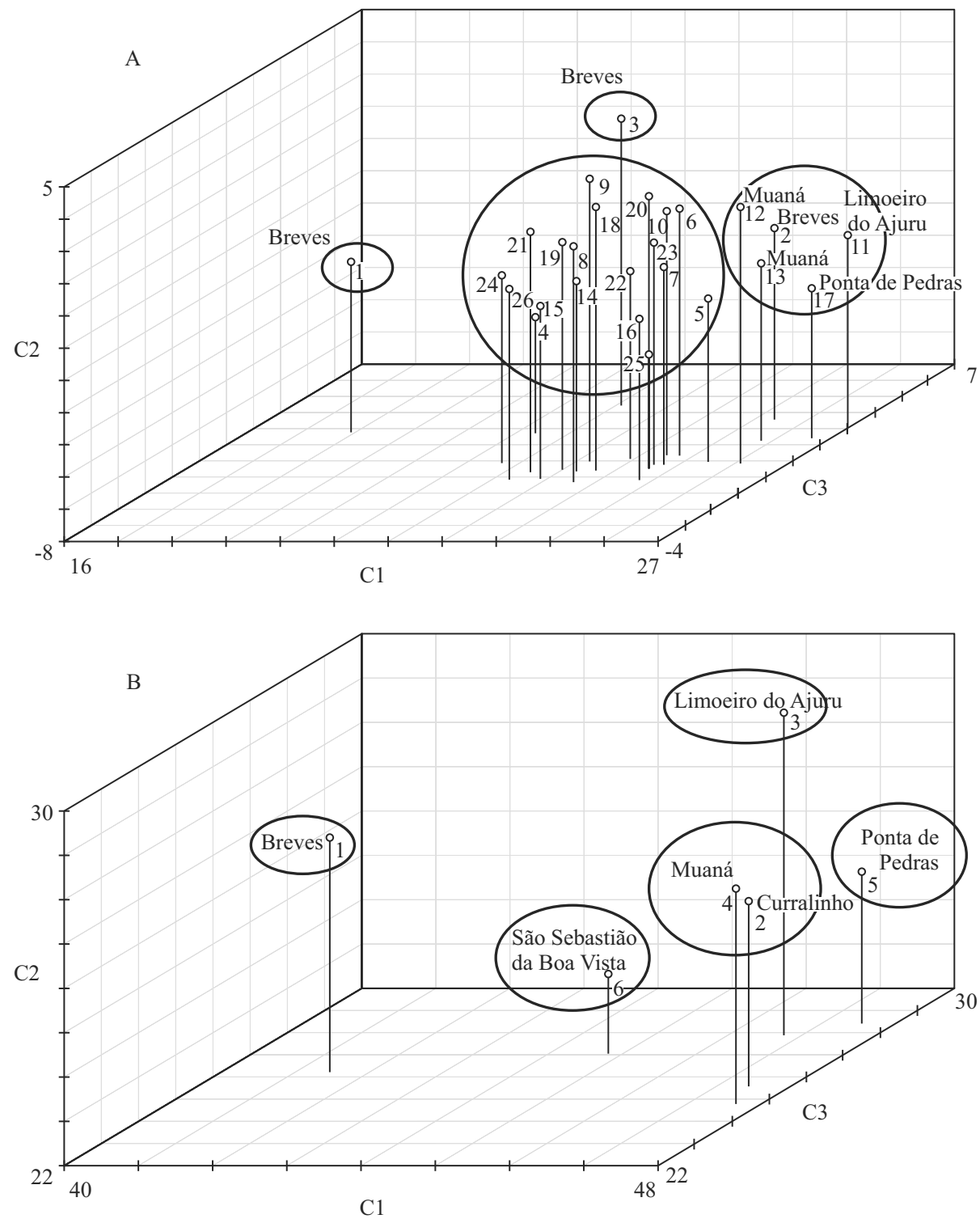

Figure 2. Graphic dispersion of 26 accessions (A) and six sources (municipalities) (B) of white-type acai palm (Euterpe oleracea), stored in the active acai palm germplasm bank of Embrapa Amazônia Oriental, located in the municipality of Belém, in the state of Pará, Brazil, based on three main components (weight of 100 fruits, number of rachillae per bunch, and fruit yield per bunch), established by the linear combination of the following 13 morpho-agronomic characters: type of stipe, number of offshoots, number of fruiting offshoots, circumference of the offshoot at chest height, length of five internodes, color of the mature fruit, total number of bunches, total bunch weight, fruit weight per bunch, fruit yield per bunch, length of the rachis of the bunch, number of rachillae per bunch, and weight of 100 fruits. 
any species, the character fruit weight can also be used as a standard and allows offering a good product for the market. Based on these results, the accessions of white-type acai palm should be sorted out according to fruit size and weight, since the character WHF most contributed to the morpho-agronomic characterization of the studied germplasm.

These results may aid in research projects, increasing scientific knowledge of white-type acai, when approached as a differentiated product, that is, as "a new type of acai".

\section{Conclusions}

1. The accessions of white-type acai palm (Euterpe oleracea) show strong genetic divergence, and the characters weight of 100 fruits, number of rachillae per bunch, and fruit yield per bunch contribute the most to this divergence.

2. The accessions obtained from the municipalities of Breves, Curralinho, and Limoeiro do Ajuru, in the state of Pará, Brazil, are the most divergent.

3. The germplasm of white-type acai palm presents genetic variability in eight of the morpho-agronomic characters evaluated, which facilitates the selection of individuals desirable for plant breeding programs.

\section{Acknowledgments}

To Coordenação de Aperfeiçoamento de Pessoal de Nível Superior (Capes), for the scholarship granted; to Embrapa Amazônia Oriental, for supporting the research; and to Universidade Federal Rural da Amazônia (UFRA), for the opportunity of expanding our knowledge.

\section{References}

AFONSO, S.D.J.; LEDO, C.A. da S.; MOREIRA, R.F.C.; SILVA, S. de O. e; LEAL, V.D. de J.; CONCEIÇÃO, A.L. da S. Selection of descriptors in a morphological characteristics considered in cassava accessions by means of multivariate techniques. Journal of Agriculture and Veterinary Science, v.7, p.13-20, 2014.

ANDRADE, R.A. de; WICKERT, E.; MARTINS, A.B.G.; ANDRADE, M.M.C. de; LEMOS, E.G. de M. Diversidade genética de acessos de Nephelium lappaceum L. através de caracterização morfológica e molecular. Comunicata Scientiae, v.2, p.91-99, 2011.

BEOVIDES GARCÍA, Y.; MILIÁN JIMÉNEZ, M.D.; COTO ARBELO, O.; RAYAS CABRERA, A.; BASAIL PÉREZ, M.;
PINO, A.S.; LÓPEZ TORRES, J.; MEDERO VEGA, V.R.; CRUZ ALFONSO, J.A.; RUIZ DÍAS, E.; RODRÍGUEZ PÉREZ, D. Caracterización morfológica y agronómica de cultivares cubanos de yuca (Manihot esculenta Crantz). Cultivos Tropicales, v.35, p.43-50, 2014.

CRUZ, C.D. Programa genes: análise multivariada e simulação. Viçosa: Ed. da UFV, 2006. v.1, 175p.

CRUZ, C.D.; FERREIRA, F.M.; PESSONI, L.A. Biometria aplicada ao estudo da diversidade genética. Visconde do Rio Branco: Suprema, 2011. 620p.

DOMICIANO, G.P.; ALVES, A.A.; LAVIOLA, B.G.; CONCEIÇÃO, L.D.C.S. da. Parâmetros genéticos e diversidade em progênies de macaúba com base em características morfológicas e fisiológicas. Ciência Rural, v.45, p.1599-1605, 2015. DOI: $10.1590 / 0103-8478 \mathrm{cr} 20140909$.

ELAMEEN, A.; LARSEN, A.; KLEMSDAL, S.S.; FJELLHEIM, S.; SUNDHEIM, L.; MSOLLA, S.; MASUMBA, E.; ROGNLI, O.A. Phenotypic diversity of plant morphological and root descriptor traits within a sweet potato, Ipomoea batatas (L.) Lam., germplasm collection from Tanzania. Genetic Reprovenances and Crop Evolution, v.58, p.397-407, 2011. DOI: 10.1007/s10722010-9585-1.

FARIAS NETO, J.T. de; OLIVEIRA, M. do S.P. de; RESENDE, M.D.V. de; RODRIGUES, J.C. Parâmetros genéticos e ganhos com a seleção de progênies de Euterpe oleracea na fase juvenil. Cerne, v.18, p.515-521, 2012. DOI: 10.1590/S0104-77602012000300020.

FARIAS NETO, J.T. de; RESENDE, M.D.V. de; OLIVEIRA, M. do S.P. de. Seleção simultânea em progênies de açaizeiro irrigado para produção e peso de fruto. Revista Brasileira de Fruticultura, v.33, p.532-539, 2011. DOI: 10.1590/S010029452011000200025.

FARIAS NETO, J.T. de; RESENDE, M.D.V. de; OLIVEIRA, M. do S.P. de; NOGUEIRA, O.L.; FALCÃO, P.N.B.; SANTOS, N.S.A. dos. Estimativas de parâmetros genéticos e ganhos de seleção em progênies de polinização aberta de açaizeiro. Revista Brasileira de Fruticultura, v.30, p.1051-1056, 2008. DOI: 10.1590/S0100-29452008000400035.

FARIAS NETO, J.T. de; RESENDE, M.D.V. de; OLIVEIRA, M. do S.P. de; SANTOS, N.S.A. dos; CANUTO, E.L.; NOGUEIRA, O.L.; MULLER, A.A. Avaliação genética de progênies de polinização aberta de acai (Euterpe oleracea) e estimativas de parâmetros genéticos. Cerne, v.13, p.376-383, 2007.

FAVACHO, H.A.S.; OLIVEIRA, B.R.; SANTOS, K.C.; MEDEIROS, B.J.L.; SOUZA, P.J.C.; PERAZZO, F.F.; CARVALHO, J.C.T. Anti-inflammatory and antinociceptive activities of Euterpe oleracea oil. Revista Brasileira de Farmacognosia, v.21, p.105-114, 2011. DOI: 10.1590/S0102695X2011005000007.

GALATE, R. dos S.; MOTA, M.G. da C.; GAIA, J.M.D.; COSTA, M. do S.S. Caracterização morfoagronômica de germoplasma de açaizeiro no nordeste paraense. Revista Brasileira de Fruticultura, v.34, p.540-550, 2012. DOI: 10.1590/S010029452012000200028.

GAlATE, R. dos S.; MOTA, M.G. da C.; GAIA, J.M.D.; COSTA, M. do S.S. Distância fenotípica entre matrizes de 
açaizeiro (Euterpe oleracea Mart.) procedentes do nordeste do Pará. Semina: Ciências Agrárias, v. 35, p.1667-1682, 2014. DOI: 10.5433/1679-0359.2014v35n4p1667.

GOMES JUNIOR, R.A.; GURGEL, F. de L.; PEIXOTO, L. de A.; BHERING, L.L.; CUNHA, R.N.V. da; LOPES, R.; PINA, A.J. de A.; VEIGA, A.S. Evaluation of interspecific hybrids of palm oil reveals great genetic variability and potential selection gain. Industrial Crops and Products, v.52, p.512-518, 2014. DOI: 10.1016/j.indcrop.2013.10.036.

MARINHO, J.A.M. Desenvolvimento do extrativismo do acai e mudanças na socioeconomia de ribeirinhos marajoaras. In: GODOI, E.P. de; MENEZES, M.A. de; MARIN, R.A. (Ed.). Diversidade do campesinato: expressões e categorias: estratégias de reprodução social. São Paulo: Ed. da Unesp, 2009. v.2, p.185210.

MENEZES, E.M. da S.; TORRES, A.T.; SRUR, A.U.S. Valor nutricional da polpa de acai (Euterpe oleracea Mart.) liofilizada. Acta Amazonica, v.38, p.311-316, 2008. DOI: 10.1590/S004459672008000200014.

NUNES, A.M.; FACHINELLO, J.C.; RADMANN, E.B.; BIANCHI, V.J.; SCHWARTZ, E. Caracteres morfológicos e físico-químicos de butiazeiros (Butia capitata) na região de Pelotas, Brasil. Interciência, v.35, p.500-505, 2010.

OLIVEIRA, M. do S.P. de; FERREIRA, D.F.; SANTOS, J.B. dos. Divergência genética entre acessos de açaizeiro fundamentada em descritores morfoagronômicos. Pesquisa Agropecuária Brasileira, v.42, p.501-506, 2007. DOI: 10.1590/S0100204X2007000400007.

OLIVEIRA, M. do S.P. de; FERREIRA, D.F.; SANTOS, J.B. dos. Seleção de descritores para caracterização de germoplasma de açaizeiro para produção de frutos. Pesquisa Agropecuária Brasileira, v.41, p.1133-1140, 2006. DOI: 10.1590/S0100204X2006000700009.

OLIVEIRA, N.P. de; OLIVEIRA, M. do S.P. de; MOURA, E.F. Variability and genetic divergence among fiber palm tree (Astrocaryum vulgare Mart.) genotypes for fruit yield by rapd markers. Revista Brasileira de Fruticultura, v.34, p.216-226, 2012. DOI: $10.1590 /$ S0100-29452012000100029.

OLIVEIRA, W.B. dos S.; FERREIRA, A.; GUILHEN, J.H.S.; MARÇAL, T. de S.; FERREIRA, M.F. da S.; SENRA, J.F. de B.
Análise de trilha e diversidade genética de Euterpe edulis Martius para caracteres vegetativos e de frutos. Scientia Forestalis, v.43, p.303-311, 2015.

RAMALHO, M.A.P.; SANTOS, J.B. dos; PINTO, C.A.B.P.; SOUZA, E.A. de; GONÇALVES, F.M.A.; SOUZA, J.C. de. Genética na agropecuária: genética quantitativa. 5.ed. rev. Lavras: Ufla, 2012. 565p.

RESENDE, M.D.V. de. SELEGEN-RELM/BLUP: sistema estatístico e seleção genética computadorizada via modelos lineares mistos. Colombo: Embrapa Florestas, 2007. 359p.

SCHUSTER, I.; VIEIRA, E.S.N.; PADILHA, L. Marcadores moleculares no pós-melhoramento. In: BORÉM, A.; CAIXETA, E.T. (Ed.). Marcadores moleculares. Viçosa: Ed. da UFV, 2006. p.205-230.

SINGH, D. Relative importance of characters affecting genetic divergence. Indian Journal of Genetic and Plant Breeding, v.41, p.237-245, 1981.

TEIXEIRA, D.H.L.; OLIVEIRA, M. do. S.P. de; GONÇALVES, F.M.A.; NUNES, J.A.R. Índices de seleção no aprimoramento simultâneo dos componentes da produção de frutos em açaizeiro. Pesquisa Agropecuária Brasileira, v.47, p.237-243, 2012. DOI: 10.1590/S0100-204X2012000200012.

VIEIRA, E.A.; FIALHO, J. de F.; FALEIRO, F.G.; BELLON, G.; FONSECA, K.G. da; SILVA, M.S.; PAULA-MORAES, S.V. de; CARVALHO, L.J.C.B. Caracterização fenotípica e molecular de acessos de mandioca de indústria com potencial de adaptação às condições do Cerrado do Brasil Central. Semina: Ciências Agrárias, v.34, p.567-582, 2013. DOI: 10.5433/1679-0359.2013v3 $4 \mathrm{n} 2 \mathrm{p} 567$.

YOKOMIZO, G.K.I.; FARIAS NETO, J.T. de; OLIVEIRA, M. do S.P. de. Ganho esperado na seleção de progênies de polinização aberta de Euterpe oleracea para produção de frutos. Scientia Forestalis, v.44, p.241-248, 2016. DOI: 10.18671/scifor. v44n109.23.

YOKOMIZO, G.K.-I.; QUEIROZ, J.A.L. de; CAVALCANTE, E. da S.; PINHEIRO, I. de N.; SILVA, P.A.R. da; MOCHIUTTI, S. Caracterização fenotípica e genotípica de progênies de Euterpe oleracea coletados no Afuá-Pará nas condições do Amapá. Cerne, v.18, p.205-213, 2012. DOI: 10.1590/S010477602012000200004 .

Received on May 30, 2016 and accepted on September 5, 2016

Pesq. agropec. bras., Brasília, v.52, n.9, p.751-760, set. 2017

DOI: 10.1590/S0100-204X2017000900007 